\title{
Evaluation of the Extraction Process of the Essential Oil from Cymbopogon schoenanthus with Pressurized Carbon Dioxide
}

\author{
Elisa Maria Bittencourt Dutra de Sousa ${ }^{*}$, Ana Paula Costa Câmara ${ }^{1}$, Wallace \\ Albuquerque Costa ${ }^{1}$, Adriano Cezar J. Costa ${ }^{1}$, Humberto Neves Maia Oliveira ${ }^{1}$, Elisângela \\ Lopes Galvão ${ }^{1}$ and Márcia Maria Ortiz Marques ${ }^{2}$ \\ ${ }^{1}$ Universidade Federal do Rio Grande do Norte - UFRN; Centro de Tecnologia; Departamento de Engenharia \\ Química; Campus Universitário s/n; 59072970; Natal - RN - Brasil. ${ }^{2}$ Instituto Agronômico de Campinas - IAC; \\ Universidade Estadual de Campinas; Campinas - SP - Brasil
}

\begin{abstract}
The objective of this work was to study the essential oil extraction process of Cymbopogon schoenanthus Spreg with pressured $\mathrm{CO}_{2}$, and to compare the results with a conventional extraction process. The experiment was conducted at $15^{\circ} \mathrm{C}, 66.7$ bar and a medium flow rate of $1.23 \mathrm{~g} \mathrm{CO} / \mathrm{min}$, in a fixed bed extractor and a dynamic method was adopted for the solubility calculation. The solvent extraction was realized with ethanol in an incubator, followed by a vacuum filtration and solvent evaporation. The composition of the oil was analyzed by a gas chromatography connected to a mass spectrometer. The extraction with $\mathrm{CO}_{2}$ showed a yield of $2.78 \%$, and solubility of $1.48 \times 10^{-2} \mathrm{~g}$ oill $\mathrm{g} \mathrm{CO}_{2}$.
\end{abstract}

Key words: Extraction; carbon dioxide, Cymbopogon schoenantus

\section{INTRODUCTION}

The use of extraction processes, utilizing fluids in close conditions of the critical area, has been presenting excellent results, characterized by discharge selectivity and excellent extraction capacity when compared with conventional extraction processes. Therefore, this technique has been applied more and more in the processes of natural products separation, which consists basically of an extraction stage, in which the compound is removed from the raw material through the contact with the fluid, and a separation stage, in which the extract is separated from the fluid by a convenient method, as well as a change of pressure and/or temperature.

\section{Cymbopogon schoenanthus}

Spreg belongs to the family of Gramineae. Originally from India, it was introduced in Brazil during the colonial period. It shows sedative, digestive and perfumed properties, with strong characteristic aroma.

Some studies also proved its action in the biological control against parasites (Ketoh et al., 2002). This species grows up to two meters height, containing short rhizomes with well demarcated knobs, prolonged leaves, linear limbo, rough in the

\footnotetext{
* Author for correspondence
} 
two faces and sharp. The leaves are covered by a fine layer of whitish wax.

The aim of this work was to study the extraction process of the essential oil of Cymbopogon schoenanthus with pressurized $\mathrm{CO}_{2}$, and to compare the results obtained with the conventional process of extraction with solvent (ethanol).

\section{MATERIAL AND METHODS}

Characterization and preparation of the samples

The samples of Cymbopogon schoenanthus Spreg were obtained from Algeria, where they were dried in the shade. The samples were conditioned initially properly in plastic bags under vacuum and stored in a freezer (Consul, model 280, Brazil). The humidity of the leaves (raw material) was determined by the method of Jacobs (1973). The reduction of the particles size was accomplished with the aid of a domestic food processor (ARNO, model PRO, Brazil), by grinding during 15 seconds. The triturated solid was sieved using a shaker with sieves of the Tyler series (Produtest, no. 3614, rheostat 10) for 15 minutes. The particle size distribution adopted for the extraction experiments was a mixture composed of 28,35 and 48 mesh, with a percentage of 50.03, 33.35 and $16.62 \%(\mathrm{w} / \mathrm{w})$, respectively.

\section{Experimental}

The equipment used for the extractions with $\mathrm{CO}_{2}$ is shown in the Fig. 1.

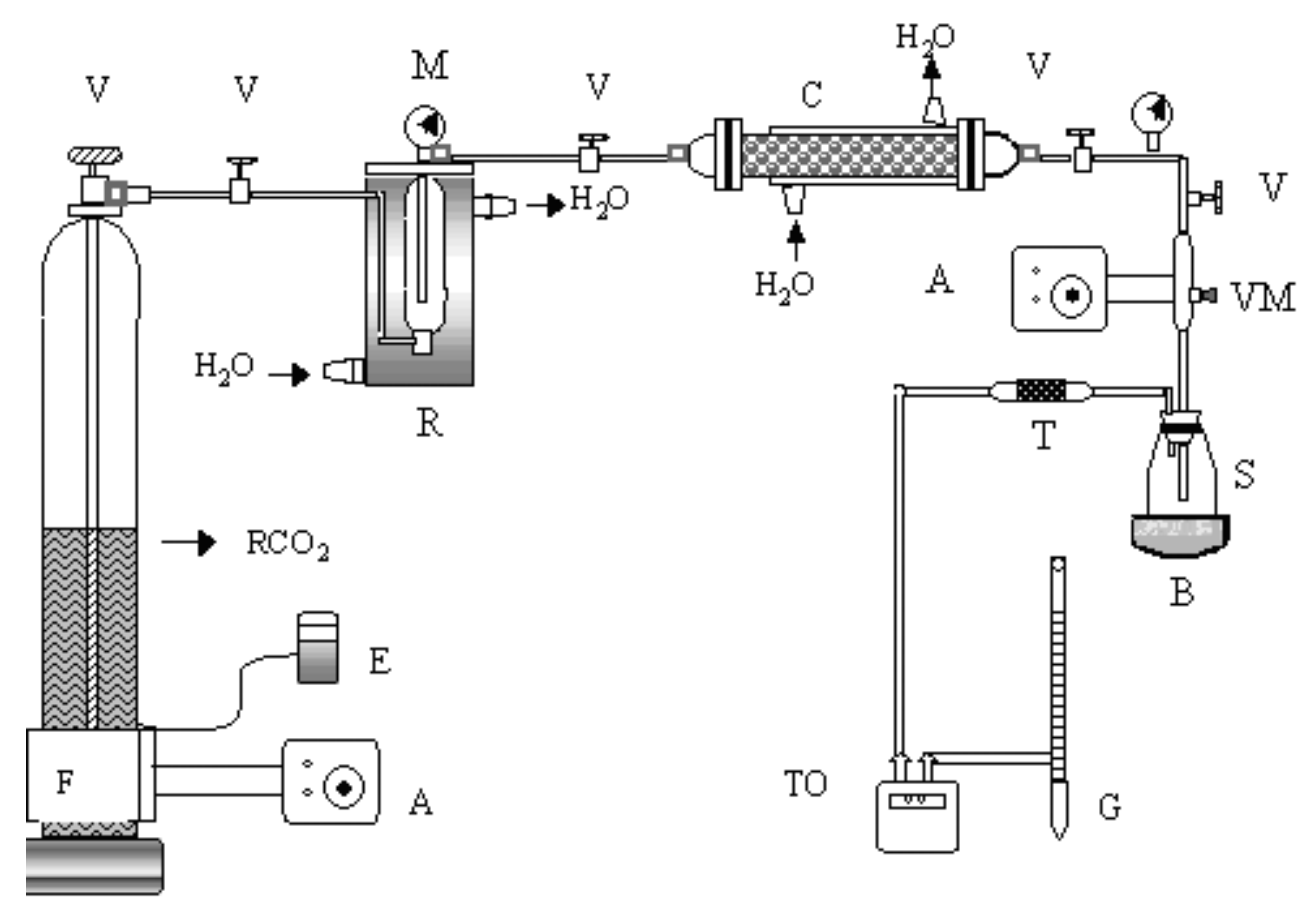

Figure 1-Extraction unit: $\mathrm{RCO}_{2}=\mathrm{CO}_{2}$ reservoir containing a siphon and capacity of $25 \mathrm{~kg} ; \mathrm{C}=$ Jacketed equilibrium cell or extractor made of stainless steel with length of $0.60 \mathrm{~m}$, diameter of $0.0216 \mathrm{~m}$ and wall thickness of $0.028 \mathrm{~m} ; \mathrm{M}=$ Manometer type Bourdon (RECORD, 004-99, 0 - $100 \mathrm{bar}$, Brazil); $\mathrm{H}_{2} \mathrm{O}=$ Water bath (TECNAL, model TE 184); $\mathrm{R}=$ Jacketed cylinder to keep the solvent as a sub cooled liquid with capacity of $0.5 \times 10^{-3} \mathrm{~m}^{3} ; \mathrm{T}=$ capillary glass tube filled with porapak-Q (Supelco, 80/100 mesh, 75CC, lot 113, USA); $\mathrm{S}=$ glass flask, capacity for $5 \mathrm{~mL} ; \mathrm{B}=$ glass recipient with ice-cubes and water; $\mathrm{A}=$ voltage regulator (VARIAC, STP - Societies Technical Paulista, model -ATV-215 M, Brazil); E = digital thermometer (LUTRON, model TM-905); F = heating tape (FISATON, model 5, Brazil); V = needle type valves (HOKE, model 3712G2Y, USA); VM = micrometric valve (HOKE, model 1335G2Y, USA); $\mathrm{G}=$ glass bublemeter; $\mathrm{TO}=$ flow totalizer (LAO, model G1, Brazil). 
The experimental apparatus consisted of a cylinder with $\mathrm{CO}_{2}$, extractor jacketed column, lung tank to stabilize the operational conditions (temperature and pressure), thermostatic bath, separator vessel, manometers, thermocouples and flux meters. The fixed bed, which filled the extractor column, was formed by $103.23 \mathrm{~g}$ of $C$. schoenanthus properly pressed with the aid of an iron stick. Following conditions were used initially to stabilize the equipment: pressure of $66.7 \mathrm{bar}$, temperature of $15^{\circ} \mathrm{C}$, and $\mathrm{a} \mathrm{CO}_{2}$ medium flow rate of $1.23 \mathrm{~g}$ $\mathrm{CO}_{2} / \mathrm{min}$.

\section{Calculation procedures}

The method used for the determination of the solubility of the oil in $\mathrm{CO}_{2}$ was as proposed by Rodrigues et al. (2002) and Sousa et al. (2002). Using the experimental data, the overall extraction curves were fitted to a spline using two straight lines. The first line was identified with the constant extraction rate period (CER). From the spline, the mass-transfer rate for the CER period $\left(\mathrm{M}_{\mathrm{CER}}\right)$ was computed, as well as the time corresponding to the interception of the two lines $\left(t_{\text {CER }}\right)$. The spline fit was done using multipleregression analysis (STATISTICA 5.5). MS Excel 2002 was used to determine the interception of the two lines. The mass ratio of solute in the supercritical phase at the equilibrium cell outlet $\left(\mathrm{Y}_{\mathrm{CER}}\right)$ was obtained dividing $\mathrm{M}_{\mathrm{CER}}$ by the mean solvent flow rate for the CER period. All the accomplished experiments were reproduced for twice

\section{Extraction by organic solvent}

Ethanol (MERCK, 99,8\%) was used as solvent for the extraction of the $C$. schoenanthus as allowed by the Brazilian legislation for use in food. The process has been described by Povh (2001): $30 \mathrm{~g}$ of the ground sample, added $180 \mathrm{~mL}$ of ethanol, incubated at $15^{\circ} \mathrm{C}, 190 \mathrm{opm}$ for $8 \mathrm{~h}$ and then filtered waves vacuum. Then, $20 \mathrm{~mL}$ of the filtrate were placed in Petri plates at $18^{\circ} \mathrm{C}$ for $48 \mathrm{~h}$, for the solvent evaporation. After this, the plates were weighed. The process was continued for another $6 \mathrm{~h}$ and plates were again weighed. The yield of the obtained extract (essential oil, waxes and pigments) was calculated dividing the extracted oil mass by the mass of the ground sample. For the calculation of the essential oil weight, the plates were placed in a greenhouse with air circulation at $165^{\circ} \mathrm{C}$, and the samples were weighed at every 30 min until constant weight. The amount of essential oil was calculated linking the lost mass in the greenhouse with the initial mass.

\section{Chemical composition of the extracts}

The extracts were analyzed in gas chromatograph coupled to a mass spectrometer system (Shimadzu, model QP-5000), equipped with capillary column DB-5 (30 m x $0.25 \mu m \times 0.25 \mu \mathrm{m}$ JandW Scientific) and operating in the following conditions: Injector: $240^{\circ} \mathrm{C}$; Detector: $230^{\circ} \mathrm{C}$; Electrons' impact: $70 \mathrm{eV}$,carrier gas: Helium; Flux: $1.0 \mathrm{~mL} /$ minute; Split ratio: $1 / 20$. The temperature programming was from: $60^{\circ} \mathrm{C}-240^{\circ} \mathrm{C}, 3^{\circ} \mathrm{C} /$ minute. The sample injected was $1 \mu \mathrm{L}$ of extract diluted in ethyl acetate, P.A. The identification of the substances was made by the comparison of its mass spectra with the database of the system CGEM (Nist. 62 lib.) and retention index (McLafferty and Stauffer, 1989 and Adams, 1995).

\section{RESULTS AND DISCUSSION}

Fig. 2 presents a typical curve of the kinetics of the extraction process of the essential oil of $C$. schoenantus in $\mathrm{CO}_{2}$ under high pressure, where such curves are characterized by the formation of three different areas: (i) the stage of constant extraction, where the solute is extracted essentially by convection; (ii) period of decrease rate, where convection and diffusion act; (iii) diffusional period, where the diffusion of the oil and of the mixture solute/solvent prevails in the solid. The process time of total extraction was 250 minutes, on average, during which $79.8 \%$ of the oil was extracted.

Table 1 presents the physical characterization of the samples of $C$. schoenanthus used in this study:

Table 1 - Characterization of the samples

\begin{tabular}{lc}
\hline & Cymbopogon schoenantus \\
\hline Medium diameter of the particle $(\mathrm{mm})$ & 0.41 \\
Humidity $(\%$ dry base) & 10.0 \\
Apparent density of bed $\left(\mathrm{g} / \mathrm{cm}^{3}\right)$ & 0.47 \\
\hline
\end{tabular}




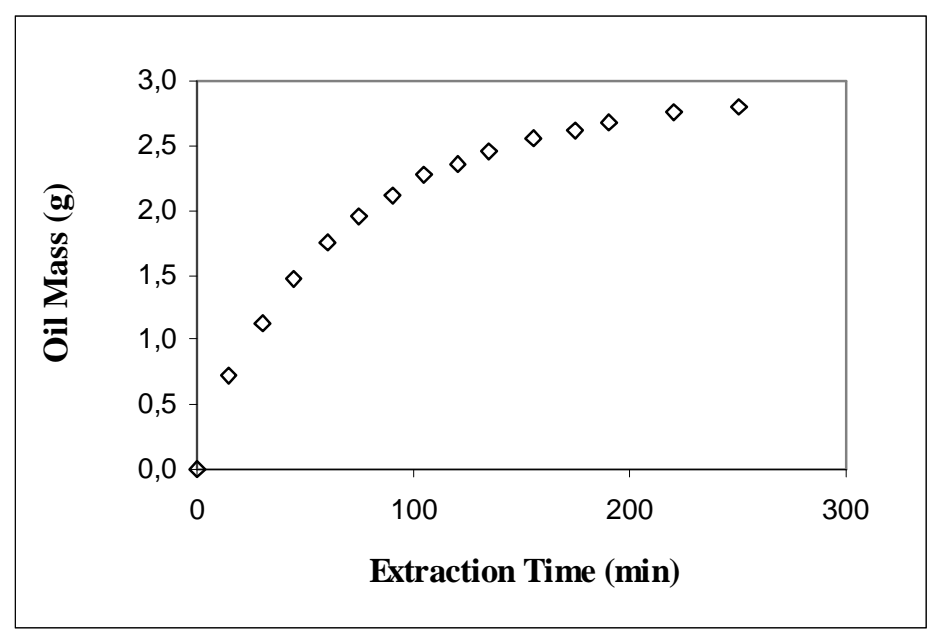

Figure 2 - Kinetic curve of the oil extraction of Cymbopogon schoenantus in pressurized $\mathrm{CO}_{2} . \mathrm{T}=15^{\circ} \mathrm{C}, \mathrm{P}=66.7$ bar; Flow rate of $\mathrm{CO}_{2}=1.23 \mathrm{~g}$ $\mathrm{CO}_{2} / \mathrm{min}$

Table 2 presents the extraction yield and the solubility of the obtained oil with pressurized $\mathrm{CO}_{2}$, and yield when ethanol was used as solvent.

It is observed that the extraction technique using ethanol as a solvent showed better total yield. However, in the total extract, pigments and waxes were also present. Thus, considering only the essential oil, extraction technique with $\mathrm{CO}_{2}$ showed better results.

Table 3 shows results in the literature about extraction yield of the C. schoenantus oil. Comparing Tables 2 and 3, it was observed that there were not significant alterations in relation to the extraction yield, even considering the differences in relation to the technique of extraction, as well as differences in relation to the cultivation area and crop periods.

Table 4 presents the identified components in the extract. A significant difference was observed in relation to the oil composition, because the ethanol extracts high amounts of sugars, oligosaccharides and other polar and not volatile compounds.

Fig. 3 and 4 present the characteristic chromatogram for the extract of $C$. schoenantus.

The main components of the oil of $C$. schoenantus were Cis-para-ment-2en-1-ol, trans-para-ment2en-1-ol and elemol for the extract using $\mathrm{CO}_{2}$ as solvent and Cis-piperitol, Trans-piperitol and elemol for the extract using ethanol as solvent.

Table 2 - Extraction yield

\begin{tabular}{ccc}
\hline & Yield $(\%)$ & 2.78 \\
\hline $\mathrm{CO}_{2}\left(15^{\circ} \mathrm{C}\right.$ e 67 bar $)$ & Total Extract & 4.00 \\
Ethanol & Essential Oil & 2.27 \\
& Solubility $\left(\mathrm{g}\right.$ oil/ $\left.\mathrm{g} \mathrm{CO}_{2}\right)$ & \\
\hline
\end{tabular}

Table 3 - Comparative results of the literature (Ketoh et al., 2002)

\begin{tabular}{cc}
\hline \multicolumn{2}{c}{ Essential Oil of Cymbopogon schoenantus } \\
\hline Origin & Togo \\
Yield (\%) & 2.75 \\
Extraction method & Steam distillation \\
\hline
\end{tabular}


Table 4 - Identified components in the extract of Cymbopogon schoenanthus

\begin{tabular}{ccccc}
\hline Components & Pick & $\begin{array}{c}\mathbf{C O}_{\mathbf{2}} \\
\text { (\%) area) }\end{array}$ & Pick & $\begin{array}{c}\text { Ethanol } \\
\text { (\%)area) }\end{array}$ \\
\hline Isosilvestrene & 1 & 1.30 & - & - \\
Limonene & 2 & 2.40 & 1 & 3.1 \\
cis-para-ment-2en-1-ol & 3 & 17.78 & 2 & 2.49 \\
trans-para-ment-2en-1-ol & 4 & 10.83 & 3 & 2.05 \\
$\alpha$ terpineol & 5 & 5.59 & 4 & 4.02 \\
cis-piperitol & 6 & 9.14 & 5 & 4.54 \\
trans-piperitol & 7 & 6.26 & 6 & 3.87 \\
Thymol & 8 & 0.73 & & - \\
cis-trimenal & 9 & 3.79 & & - \\
germacrene D & 10 & 1.19 & 7 & - \\
$\beta$-selinene & 11 & 1.05 & 8 & 3.11 \\
$\delta$-cadinene & 12 & 0.54 & 9 & 27.19 \\
Elemol & 13 & 13.71 & 10 & 3.74 \\
$\alpha$-eudesmol & 14 & 2.23 & 1.07 & 1.53 \\
\hline
\end{tabular}

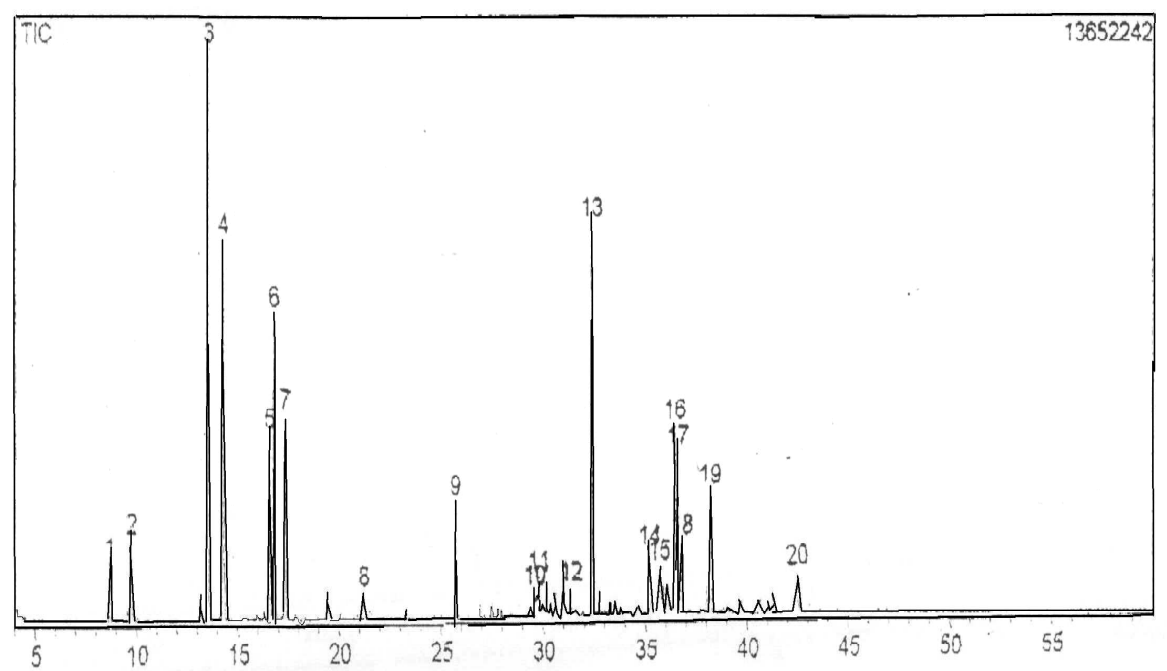

Figure 3- Chromatogram of the obtained extract using the $\mathrm{CO}_{2}$ as solvent.

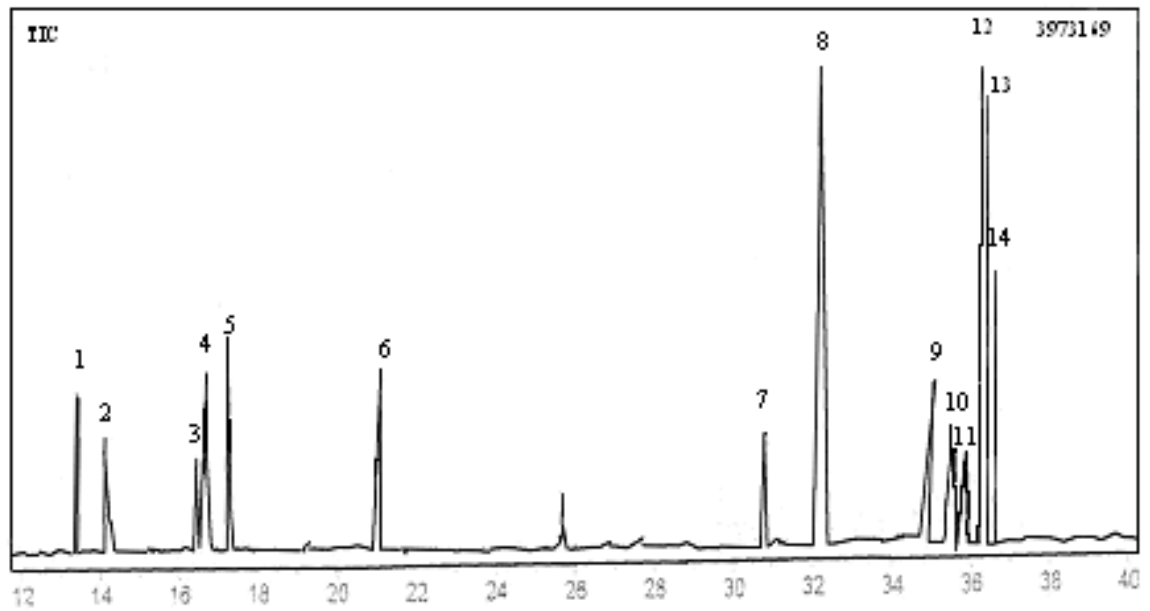

Figure 4 - Chromatogram of the obtained extract using ethanol as solvent. 


\section{CONCLUSIONS}

The process showed viability for the extraction of the oil, which was clear and limpid. The extraction yield and the solubility of the oil were satisfactory, showing no significant changes in relation to the technique and origin. The main components of the oil of $C$. schoenantus were Cis-for-ment-2en-1-ol, trans-for-ment-2en-1-ol and elemol.

\section{RESUMO}

O objetivo deste trabalho é apresentar um estudo do processo de extração do óleo essencial de Cymbopogon schoenanthus Spreg com $\mathrm{CO}_{2}$ pressurizado, e comparar os resultados obtidos com um processo convencional de extração. Os experimentos foram realizados numa temperatura de extração de $15^{\circ} \mathrm{C}$, pressão de 66,7 bar e vazão média de $1,23 \mathrm{gCO}_{2} / \mathrm{min}$. O processo ocorreu num extrator em leito fixo e foi adotado o método dinâmico para o cálculo da solubilidade. A extração com solvente orgânico foi realizada com etanol através de uma incubadora a $15^{\circ} \mathrm{C}$, seguida de filtração a vácuo e posterior evaporação do solvente. A composição do óleo foi analisada por cromatografia gasosa acoplada a espectrômetro de massa. A extração com $\mathrm{CO}_{2}$ apresentou um rendimento de $2,78 \%$ e solubilidade de $1,51.10^{-2} \mathrm{~g}$ óleo/g $\mathrm{CO}_{2}$.

\section{REFERENCES}

Adams, R. P. (1995), Identification of essential oil components by gas chromatography/mass spectroscopy. Allured Publishing Corporation. 468 pp.

Jacobs, M. B. (1973), The Chemical Analysis of Food Products. 3. ed. New York : Robert Krieger, Publishing Co.

Ketoh, G. K.; Glitho, A. I. and Huignard, J. (2002), Susceptibility of the bruchid Callosobruchus maculates (Coleoptera: bruchidae) and its parasitoid Dinarmus basalis (Hymenoptera:pteromalidae) to three essential oils; Journal of economic entomology, 95 : (1), 174-182.

McLaferty, F. W. and Stauffer, D. B. (1989), The wiley/NBS Registry of mass spectral data. New York: John Wiley and Sons. v. 1/2. 3139 pp.

Povh, N. P.; Meireles, M. A. A. and Marques, M. O. M. (2001), Supercritical $\mathrm{CO}_{2}$ extraction of essential oil and oleoresin from chamomile (Matricaria recutita (L.) Rauschert). In: International Meeting on High
Pressure Chemical Engineering, 2., Hamburgo. Proccedings... Hamburgo.

Rodrigues, V. M.; Sousa, E. M. B. D.; Monteiro, A. R.; Chiavone-Filho, O.; Marques, M. O. M. and Meireles, M. A. A. (2002), Determination of the Solubility of Extracts from Vegetable Raw Material in Pressurized $\mathrm{CO}_{2}$ : a Pseudo - Ternary Mixture Formed by Cellulosic Structure + Solute + Solvent, J. Supercritical Fluids, 22, 21-36.

Sousa, Elisa M. B. D.; Chiavone Filho, O; Moreno, M. T.; Silva, D. N.; Marques, M. and Meireles, M. A. (2002), Experimental results for the extraction of essential oil from Lippia sidoides cham using pressurized carbon dioxide, Brazilian Journal of Chemical engineering, 19 : (2), 229-241.

Received: September 29, 2004; Revised: February 25, 2005; Accepted: March 25, 2005. 